
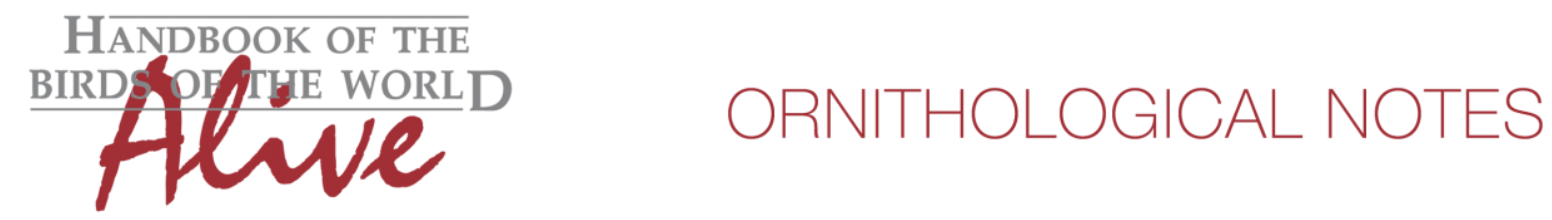

\title{
Notes on the vocalizations of Yellow-breasted Flycatcher (Tolmomyias flaviventris)
}

Peter Boesman

In the following we briefly analyze and compare voice of the different races of Yellowbreasted Flycatcher (Tolmomyias flaviventris). We also try to quantify the extent of any vocal differences using the criteria proposed by Tobias et al. (2010), as a support for taxonomic review. We have made use of sound recordings available on-line from Xeno Canto (XC).

There are clearly 2 vocal groups (Fig. 1):
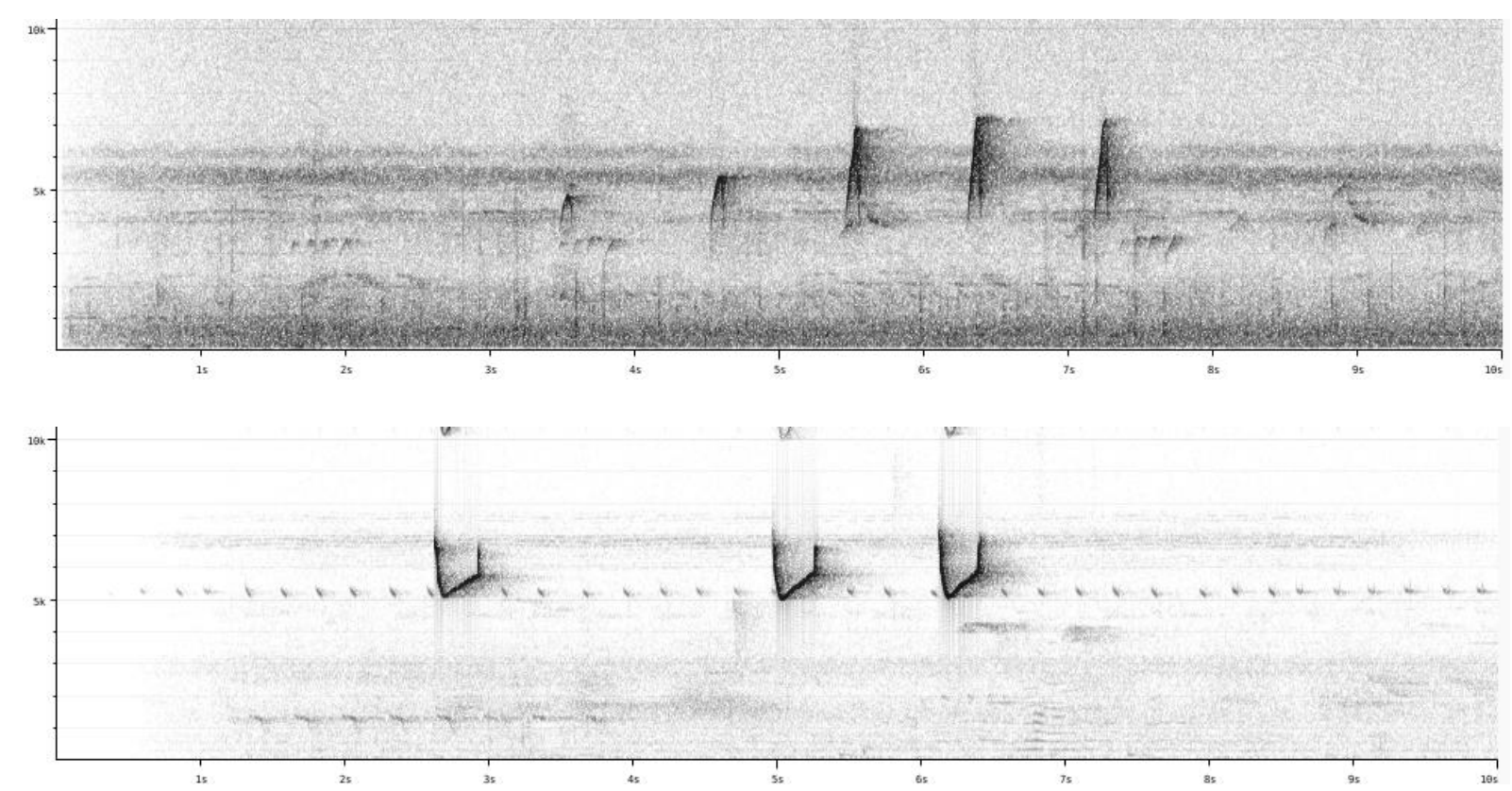

Figure 1: typical song of W Amazon group (top) and other races (bottom)

W Amazon birds (T. f. viridiceps T. f. zimmeri T. f. subsimilis) (with recordings only in E Ecuador and entire E Peru. The exact boundaries in Colombia, Brazil and Bolivia thus to be further explored, but birds from Beni (Bolivia), Rondonia (Brazil) and C Colombian Amazon lowlands belong to the other vocal group).

Song is a series of 4-7 short overslurred notes, first 3 rising in pitch, then at about same pitch.

max. note length

$0.010-0.12 \mathrm{~s}$

max. freq.

freq. range

$5600-7000 \mathrm{~Hz}$

\# of notes

$2200-4000 \mathrm{~Hz}$

4-7

\section{Other races (T. f. aurulentus, $T$. f. dissors $T$. f. flaviventris)}

Song is a rather drawn-out high-pitched note, typically underslurred but often quite irregularly modulated. Usually uttered in loose series without clear pattern.

max. note length

max. freq.

freq. range

\# of notes
$0.27-0.46 \mathrm{~s}$

$5500-7000 \mathrm{~Hz}$

$1500-2500 \mathrm{~Hz}$

no clear pattern 

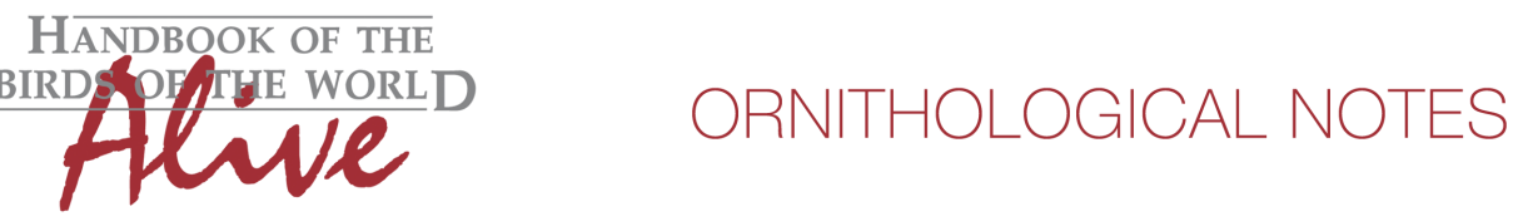

Song of W Amazon birds is very different, having much shorter notes (score 3) with a larger frequency range (score 1-2), a different note shape (score 1-2) and a clear song pattern of 4-7 notes (score 2). When applying Tobias criteria, this would result in a total vocal score of 5.

This note was finalized on 2nd July 2015, using sound recordings available on-line at that moment. We would like to thank in particular the many sound recordists who placed their recordings for this species on XC.

\section{References}

Tobias, J.A., Seddon, N., Spottiswoode, C.N., Pilgrim, J.D., Fishpool, L.D.C. \& Collar, N.J. (2010). Quantitative criteria for species delimitation. Ibis 152(4): 724-746.

\section{Recommended citation}

Boesman, P. (2016). Notes on the vocalizations of Yellow-breasted Flycatcher (Tolmomyias flaviventris). HBW Alive Ornithological Note 123. In: Handbook of the Birds of the World Alive. Lynx Edicions, Barcelona. (retrieved from http://www.hbw.com/node/932046 on 4 August 2016). 